\title{
Attitude Assessment In Learning English Based On The 2013 Curriculum For Junior High Schools
}

\author{
Eni Sumarni ${ }^{1}$, Samsudi $^{2}$, Sukestiyarno $^{3,}$ Achmad Rifai $^{4}$ \\ \{ sumarnieni60@gmail.com ${ }^{1}$, samsudi.prof@gmail.com², sukestiyarno@gmail.com ${ }^{3}$ \}
}

SMP Negeri I Bengkayang, Graduate School of Universitas Negeri Semarang, Indonesia

\begin{abstract}
The implementation of attitude assessments in the 2013 curriculum still faces problems. The large number of indicators and assessments carried out separately for each attitude during the learning process are not proportional to the time available so that attitude assessment is difficult to carry out optimally. This study aims to help English teachers overcome difficulties in assessing attitudes. This is a qualitative research that produces descriptive data in the form of written words in the simplifying attitude assessment indicators in the 2013 curriculum. This uses explanatory research. Data collection uses techniques, questionnaires, observation and documentation. The results of this study are expected to help Junior High School English teachers in assessing attitudes easily and correctly.
\end{abstract}

Keywords: Attitude Assessment, Teacher Competence, 2013 Curriculum

\section{Introduction}

It is not easy to assess the attitudes of students. It is carried out separately for each attitude and is not balanced with the time available because it must be carried out in the learning process. It is also caused by the ability or something that will be measured in students as a hidden characteristic and the right measurement tool is needed ${ }^{[1]}$. The curriculum is a set of plans and arrangements regarding the purpose, content, and material of learning and the methods used as guidelines for the implementation of learning activities to achieve certain educational goals ${ }^{[2]}$. Understanding implementers in the field in implementing change greatly determine the fate of Curriculum 2013 so as not to run aground on the road ${ }^{[3]}$. Requires understanding and competence of the teacher to implement $\mathrm{it}^{[4]}$. As a result, the attitude assessment cannot be carried out maximally. Teacher competency is knowledge, skills and abilities that are mastered by someone who has become a part of the teacher, so he can do cognitive, affective and psychomotor behavior as well as possible ${ }^{[5]}$ Pedagogic competence is an ability relating to students' understanding and management of learning that is educational and dialogical ${ }^{[6]}$.The main competency that must be possessed by a teacher so that learning is done effectively and dynamically is pedagogical competence ${ }^{[7]}$.

Attitude assessment implies an attempt to obtain various information on a continuous and comprehensive basis on the processes and results of growth and the development of attitudes and behaviors achieved by students ${ }^{[8]}$. The application of character education in schools that is integrated in learning certainly aims to foster positive character ${ }^{[9]}$. Attitude assessment can be done with the following techniques: observations, self assessment, peer evaluations, journals and interviews ${ }^{[10] .}$ This paper is about the simplification of attitude assessment based on the 
2013 curriculum which aims to help Junior High School English teachers in overcoming the problem of difficulty in assessing attitudes.

\section{Method}

This is a qualitative research. It is a study aimed at understanding phenomena which then become problems that must be overcome. This research was conducted to overcome the difficulties of English teachers in assessing attitudes. The problems are the large numbers of attitude assessment indicators and attitude assessments that have been carried out separately according to each attitude which are then combined to obtain attitudinal values not comparable to the time available. Because it must be carried out in learning process. As a result, attitude assessments were carried out in a minimum and even seemed neglected. This is a big problem that cannot be tolerated and a solution must be found immediately. Data collection techniques are done by questionnaire, observation and documentation. Questionnaires are a technique of gathering information through questionnaires to the teachers. Observations made related to the phenomenon of the phenomenon that occurs. Documentation is a record of events that have occurred.

\section{Results and Discussion}

The implementation of attitude assessment in 2013 curriculum is divided into two parts: (1) The main, consisting of observations made by subject teachers, is carried out during the learning process except religious education teachers and Pancasila and Citizenship education and observations made by classroom teachers and counseling teachers carried out outside the learning process and from valid information. (2) Supporters, consisting of evaluations between friends and self-assessment conducted at the end of the semester. The following tabel are described a number of attitudes expressed in the 2013 Curriculum for levels of Junior High School / MTs.

Table 1: List of Description Indicators

\begin{tabular}{ll}
\hline \multicolumn{1}{c}{ Attitudes and Definitions } & \multicolumn{1}{c}{ Description of Indicators } \\
\hline SPIRITUAL ATTITUDE & $\begin{array}{l}\text { 1. Pray before and after doing something } \\
\text { 2. Carry out worship on time }\end{array}$ \\
Respect and & $\begin{array}{l}\text { 3. Giving greetings before and after the presentation according to the } \\
\text { religion adopted }\end{array}$ \\
appreciate the & $\begin{array}{l}\text { 4. Thankful for the blessings and gifts of God } \\
\text { 5. Gratitude for human ability to control themselves } \\
\text { religion adopted }\end{array}$ \\
$\begin{array}{l}\text { 6. Say thank you when you succeed in doing something } \\
\text { 7. Surrendered (trust (after endeavors or do something } \\
\text { 8. Maintain the environment around homes, schools and communities } \\
\text { 9. Maintaining good relationships between fellow God's people } \\
\text { 10. Thank God Almighty as an Indonesian nation } \\
\text { 11. Respect for others to carry out worship according to their religious } \\
\text { teachings }\end{array}$ \\
1. Not cheating on the exam / test
\end{tabular}




\author{
1. Honest: \\ It is trustworthy behavior in \\ words, actions and work
}

\section{Discipline:}

It is an action that shows orderly behavior and complies with various rules and regulations

\section{Responsibility:}

Is the attitude and behavior of a person to carry out the duties and obligations that he should do to himself, the environment (nature, social, culture), the state and God Almighty

\section{Tolerance:}

Is an attitude and action that respects the diversity of backgrounds, views and beliefs

\section{Mutual cooperation:} It is working with others to achieve common goals by sharing tasks and helping sincerely

\section{Polite :}

Is a good attitude in good relations in language and behavior. Normality of politeness is relative, meaning that a good is not necessarily good / santumn at a different place and time
2. Not being a plagiarism (taking other people's writing without mentioning the source)

3. Express feelings as they are

4. Submit to authorized items found

5. Create reports based on data and information as is

6 . Recognize mistakes or shortcomings that are owned

1. Arrive on time

2. Comply with joint / school rules and regulations

3 . Work on and collect assignments according to the time specified

4. Following the rules of written language that are good and correct

1. Carry out individual tasks properly

2. Accept the risk of the actions taken

3. Do not blame / accuse other people without accurate evidence

4. Return borrowed items

5. Recognize and apologize for mistakes made keepingpromises

6. Not blaming other people for mistakes made bythemselves

7. Carry out what was said without being told or asked

1. Does not interfere with friends who have different opinions

2. Accept agreements even though they differ from their opinions

3. Can accept the shortcomings of others

4. Can forgive the mistakes of others

5. Able and willing to cooperate with anyone who has a diversity of backgrounds, views and beliefs

6. Not imposing opinions or self-beliefs on others

7. Willingness to learn from (open to) other people's beliefs or ideas in order to understand others better

8. Open to or willing to accept something new

1. Being active in working devotional cleansing in class or at school

2. Willingness to do assignments according to agreement

3. Willing to help others without expecting a reward

4. Active in group work

5. Focus on group goals

6. Do not put personal interests first

7. Look for ways to overcome differences of opinion /thoughts between yourself and others

8. Encouraging others to work together in achieving common goals

1. Respect for older people

2. Don't say rude, dirty, and arrogant

3. Do not spit anywhere

4. Don't interrupt the conversation at the wrong time

5. Say thank you after receiving help from others

6. Give Greetings, Keep giving Smile

7. Request permission when you want to enter the room -

8. Request permission when going into another person's room or using someone else's property

9.Treat others as you want to be treated 
7. Self-confidence:

There is a mental

and psychological condition for someone who

gives a strong

belief to act / act

8. Care:partisanship to involve themselves in problems, or conditions that occur around us
1. Arguing or doing activities without hesitation

2. Able to make decisions quickly

3. Not easily discouraged

4. Not awkward in acting

5. Dare to present in front of the class

6. Dare to argue, ask questions and answer questions

1. Helping friends who have difficulty in learning English

2. Bring English books and stationery, maintain cleanliness,security, order during the process of learning English.

Attitude assessment in the 2013 curriculum was carried out separately for each attitude. The results of each attitude assessment are then combined to obtain attitude values. It requires a lot of time to do, while attitude assessment must be carried out in learning process.Markle \& O'Banion (2014) states that there are still very few teachers who conduct affective assessments well in the field. So, it is not surprising that in practice so far the character is taught only as try and error, characters are not taken seriously ${ }^{[11]}$. The only way to overcome this problem is just simplify the indicators and carry out the attitude assessment in one unit at the same time and not be done separately as in the current 2013 curriculum so that attitude assessment can be done easier and does not need a long time. The following table is the simplification of the aspects of attitude that must be observed which is carried out in unity and at the same time. It is created to facilitate the Junior High School English teachers in assessing attitudes easily. This is the novelty.

Table 2: Attitudes \& Indicators of Observation in Learning English

\begin{tabular}{|c|c|c|}
\hline Attitudes & Indicators of Observation in Learning English & $\begin{array}{l}\text { DONE } \\
\text { Yes/No }\end{array}$ \\
\hline 1. Honest & $\begin{array}{l}\text { 1. Don't lie, cheat or do plagiarism in doing English } \\
\text { assignments or examinations. }\end{array}$ & \\
\hline 2. Discipline & $\begin{array}{l}\text { 2. On time in submitting asignments and attendance } \\
\text { the English class } \\
\text { 3. Obey the grammar and school discipline. }\end{array}$ & \\
\hline $\begin{array}{l}\text { 3. Responsi } \\
\text { bility }\end{array}$ & $\begin{array}{l}\text { 4. Do English assignments correctly, keep promises, return loan } \\
\text { items, don't blame others without proof, confess and accept the } \\
\text { risk of each action. }\end{array}$ & \\
\hline 4.Tolerance & $\begin{array}{l}\text { 5. Receive agreements or opinions of other studentsthough } \\
\text { different, able to work with students different backgrounds, } \\
\text { forgive and accept lack ofothers. }\end{array}$ & \\
\hline $\begin{array}{l}\text { 5. Mutual } \\
\text { cooperation }\end{array}$ & $\begin{array}{l}\text { 6. Prioritizing common interests and goals, active and can } \\
\text { cooperate in working on English group. }\end{array}$ & \\
\hline 6. Polite & $\begin{array}{l}\text { 7. Respect to teachers or older people, no say rude ordirty, } \\
\text { arrogant, not spit carelessly, not interrupting the conversation on } \\
\text { the wrong time, say thank you after receiving help, ask } \\
\text { permission when enter someone else's room or use others } \\
\text { property, give greetings, smile. }\end{array}$ & \\
\hline $\begin{array}{l}\text { 7. Self-Con } \\
\text { fidence }\end{array}$ & $\begin{array}{l}\text { 8. Quickly make a decision, dare to present or argue, } \\
\text { ask or answer when learning English }\end{array}$ & \\
\hline
\end{tabular}


8. Care 9 . Helping friends who have difficulty in learning English

10. Bring English books and stationery, maintain cleanliness, security, order during the process of learning English.

\section{Total}

Scoring instructions: Answer Yes given a score of 1, and the answer Not given a score of $O$ Attitude assessment is carried out in learning process, the value is obtained from the following calculations: TVEM score

The formula: $\quad x 4=$ Observation Score

Example:

\section{NMOS}

$$
\text { Observation score: } \frac{(8+9+7+8+9+7+7+8+8+7+8+7+8+8+7+7)}{16}
$$

Student get Observation score: Good

Information:

TVEM : Total Value of Each Meeting (in one semester)

NMOS : Number of Meetings in One Semester

Very Good (VG) : a score of $3.20-4.00(80-100)$

Good $(\mathrm{G}) \quad$ : a score of $2.80-3.19(70-79)$

Enough (E) : : a score of $2.40-2.79(60-69)$

Less (L) : score less than $2.40(<60 \%)$

Source: Permendikbud No. 81 A 2013

In addition to the attitude assessment through observations, there are also self-assessment and evaluation between friends conducted at the end of semester. They use the same indicators. The three types of attitude assessment use the same scoring method, the final result of which is the results after the three results are added then divided by three. Example of scoring in self-assessment and evaluation between friends:

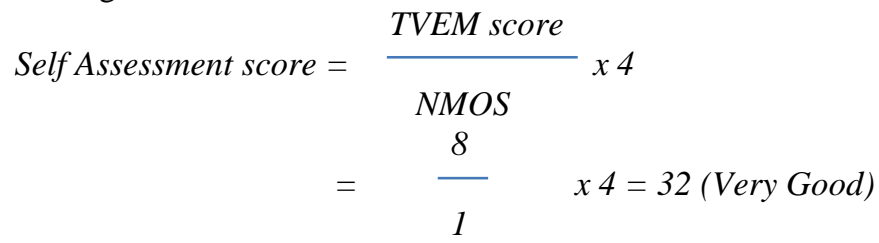

In the same way, Evaluation between friends : 28 (Good)

Final attitude score $=\frac{30,37+32+28}{3}=30,12($ Good $)$

Formulation of attitude descriptions based on the tendency to obtain value achievements. Example: Attitudes are good, but disciplinary attitudes still need to be improved.

\section{Conclusion}

The problems faced by Junior High School English teachers are the difficulty in assessing student attitudes due to the large number of indicators that must be observed, must be done one by one separately for each attitude and then combined to get attitude values. It takes a 
long time and it's not worth the time available because attitude assessment must be carried out in learning process. As a result, the attitude assessment was not optimal and seemed to be ignored. This problem must be solved immediately. Simplifying indicators in attitude assessment and carried out in one unit and not done separately for each attitude is a solution that can be done to overcome this problem. So that the teachers can assess attitudes easily and maximally. 


\section{References}

[1] Mulyasa, E.:Menjadi Guru Profesional. Remaja Rosdakarya, Bandung. (2011)

[2] Nuh, M. : Kurikulum 2013. Sumber: http://www. kemdiknas. go. id. Accessed April 29, 2019.(2013)

[3] Melati, E.R., \& Utanto, Y.: Kendala Guru Sekolah Dasar dalam Memahami Kurikulum 2013. Indonesia Journal of Curriculum and Educational Technology Sturdies, 4(1). 19. (2016)

[4] Darna : "Kesulitan Guru Dalam Mengembangkan Penilaian Sikap PesertaDidik Di SDN 75 Locok Kab ENREKANG”.(Universitas Islam Negeri Alauddin Makassar).Semarang.(2016).

[5] Niarsa, A.: Studi Kompetensi Guru Dalam Memanfaatkan Media Pembelajaran Berbasis Teknologi Informasi Dan Komunikasi (TIK) DI SD Negeri 01 Ledok Kecamatan Sambong Kabupaten Blora. Universitas Negeri Semarang. (2013)

[6] Pujiastuti, E., Raharjo, T. J., \& Widodo, A. T.: Kompetensi profesional, pedagogik guru IPA, persepsi siswa tentang proses pembelajaran, dan kontribusinya terhadap hasil belajar IPA di SMP/MTs Kota Banjarbaru. Innovative Journal of Curriculum and Educational Technology, 1(1).(2012)

[7] Umam, N. C.: Pengaruh Kompetensi Pedagogik Guru Dan Fasilitas Belajar Terhadap Hasil Belajar Mata Pelajaran Mengelola Kearsipan Pada Siswa Kelas XI Jurusan Administrasi Perkantoran SMK TAMAN SISWA KUDUS. Universitas Negeri Semarang. (2010)

[8] Rusilowati, A., Binadja, A., \& Mulyani, S.: Mitigasi Bencana Alam Berbasis Pembelajaran Bervisi Science Environment Technology and Society. Jurnal Pendidikan Fisika Indonesia, 8(1). (2012)

[9] Susanti, E. L, Sukestiyarno, Y., \& Sugiharti, E.: Efektivitas Pembelajaran Matematika Dengan Metode Problem Posing Berbasis Pendidikan Karakter. Unnes Journal of Mathematics Education, 1(1).(2012)

[10] Kunandar : Penilaian Autentik: Penilaian Hasil Belajar Peserta Didik Berdasarkan Kurikulim 2013. PT Raja Grafindo Persada Jakarta.(2013)

[11] Munawaroh, S. B., Sukestiyarno, Y. L., \& Masrukan, M :High School Mathematics Curriculum Development Integrated with Character Education Within Project Assessment as Spiral System Leveled. Unnes Journal of Mathematics Education, 6(2), 163-173. (2017) 